\title{
RESEARCH
}

Open Access

\section{Performance, behaviour and organization of maize trading in Malawi}

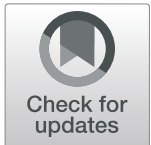

\author{
Henry Kankwamba ${ }^{1 *}$ (D) and Lukas Kornher ${ }^{2}$
}

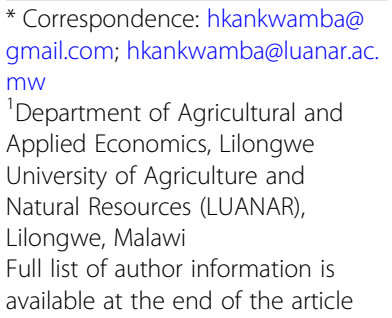

* Correspondence: hkankwamba@ gmail.com; hkankwamba@luanar.ac. mw

${ }^{1}$ Department of Agricultural and Applied Economics, Lilongwe University of Agriculture and Natural Resources (LUANAR), Lilongwe, Malawi

Full list of author information is available at the end of the article

\begin{abstract}
Industry structure and social capital could affect traders, market performance and distribution of economic resources such as food. This study assesses the effect of industry structure and social capital on traders' profitability and resilience. We use Bayes Model Averaging regression techniques to draw inferences from a random, representative and systematically selected sample of maize traders in the central region of Malawi. We complement our results with key informant prior information from industry experts and literature. Results indicate that at the local market level, few traders dominate but competition increases when we consider the entire district and region. Results also show that interaction with distant traders and brokers is associated with more profitable and resilient businesses. While we find evidence that social capital is positively associated with business profitability, results do not strongly support the hypothesis that other measures of social capital such as tribal and religious affiliation have an effect on traders' resilience. Noteworthy, as the unit of closeness among traders decreases to family ties, profits tend to increase. This suggests a more group and kin selective evolutionary stable strategy among maize traders.
\end{abstract}

Keywords: Profitability, Social capital, Resilience, Bayesian regression, Herfindahl Index, Maize traders, Kin selection

\section{Introduction}

Industry structure can alter competitiveness and growth prospects of most sectors in an economy. Emergence of highly concentrated industries may deter new entrants and may lead to inefficient allocation of resources in the market (Poulton et al. 2006; Porto et al. 2011; Sexton and Xia 2018). Highly concentrated markets might not be particularly good for food commodities especially when commodities are heavily consumed by the poor. Concentration can drive out small firms, scare potential investors and exacerbate avoidable crises (Sexton and Xia 2018).

Few studies have been conducted to document and assess the complex relationship between food industry structure, traders' productivity, performance, resilience and the role of institutions of developing economies. For example, Sitko et al. (2018) found no evidence of market concentration when large firms entered into smallholder grain markets but rather found that the retail prices of grain declined due to improved market efficiency. Gabre-Madhin (2001), using a new institutional economics perspective, assessed market institutions, transaction costs, and social capital in the Ethiopian grain market and found that social capital enhances trader productivity. Further, Fafchamps

(c) The Author(s). 2019 Open Access This article is distributed under the terms of the Creative Commons Attribution 4.0 International License (http://creativecommons.org/licenses/by/4.0/), which permits unrestricted use, distribution, and reproduction in any medium, provided you give appropriate credit to the original author(s) and the source, provide a link to the Creative Commons license, and indicate if changes were made. 
and Minten (2001), using survey data from traders in Madagascar, found high large social capital effects on firm productivity.

We define social capital as the structure of informal social relationships conducive to developing cooperation among economic actors aimed at increasing the social product. The social product is then expected to accrue to the group of people embedded in those relationships (Hayami 2009). Social capital among traders may help reduce transaction costs if traders interact more over longer periods of time (Fafchamps and Minten 2001). However, such interactions may also affect efficiency outcomes as markets may become dominated by small groups of traders that are well acquainted.

Using structural, relational and cognitive indicators for social capital, most literature from developed countries suggest a positive association between social capital and business performance (see Islam et al. 2018; Liu and Li 2018; García-Villaverde et al. 2018; Miao et al. 2017). To illustrate, Islam et al. (2018) found that cognitive ability, education, experience and the number of connections a manager possessed had a positive influence on a cooperative's performance. Further, Miao et al. (2017) assessed the effect of social capital and business performance and found that the link between social capital and performance is mediated by human capital-education and skills of employees and entrepreneurial orientation which is the strategic, philosophical and behaviours in decision-making-of the trader. In a similar manner, Asiaei and Jusoh (2015) indicated that relational and social capital improve business performance.

Further, other literature asserts that productivity, specifically profits, may be reduced if traders trade and interact with close relatives. For example, Levine et al. (2014) reported that ethnic proximity of traders may promote price bubbles and thereby bring about undesirable market outcomes such as market inefficiency. In addition, Atmadja et al. (2016) found that firms that are run by ethnically cohesive individuals perform poorly on indicators such as profitability and survivability-i.e. resilience measured as time in years a business stays profitable before closure. However, de Oliveira and Nisbett (2018) argue that there may not be much differences in outcomes from ethnically diverse groups than homogenous groups. In addition, Portes (2014) argued that social capital might drive marginalism such that individuals without significant social capital may be ostracized, face significant barriers to growth and eventually be left out of economic systems. This becomes particularly difficult when the individuals are poor traders in developing countries. To a greater extent, the link between business performance and behavioural aspects of traders such as social capital and informal arrangements such as trust relationships provide mixed evidence (Van Rijn et al. 2012). Interestingly, in Africa, where most staple food microenterprises, and therefore the transactions therein, are informal do not feature much in the debate on social capital versus business performance. As such, it is important to explore the role and implications of social capital on such economic outcomes.

The main objective of this study is to assess the effect of industry structure and social capital on maize traders' behaviour, business resilience and profitability in Malawi. We use a randomly sampled, market level representative data set involving small- to medium-scale maize traders where we ask about trade volumes, value of stock, proportion of costs, prices, pricing behaviour and whether the enterprise exports or not to ascertain the structure, conduct and performance of the firm. We also ask questions about the nature of the traders' relationship with fellow traders, brokers, lenders and 
family relations to get information regarding the structure of social networks which might have a bearing on the nature of transaction costs. Further, the study also uses key informant interviews, focused observations and group discussions with industry representatives, grain traders' associations and farmer associations. We hypothesize that traders who interact more with other traders, brokers and lenders will have more resilient and profitable businesses. To test our hypothesis, we econometrically analysed the data using Bayes Model Averaging (BMA) regression techniques. BMA analysis reduces model uncertainty by taking advantage of the posterior probability distributions of all competing model parameters conditional on the observed data and some prior knowledge (see Hoeting et al. 1999; Genell et al. 2010; Laffineur et al. 2017). In this study, we are able to use the sample data together with prior knowledge gathered from key informants and available literature to draw inferences about the organization of maize markets and the behaviour of maize traders.

The study contributes to the literature on understanding drivers of business resilience, food policy design and industrial organization by bringing recent evidence from a developing country's staple food industry and also complementing and triangulating results from methodologically different viewpoints namely qualitative and Bayesian regression analysis. This would make our interpretation of results particularly rich and highly informative.

We find two consistent results that social capital enhances business resilience and that not all forms of social capital make maize trading profitable but when traders are very close, even to family ties, profits increase.

The rest of the paper is structured as follows. We explain how we conducted the study in "Materials and methods". In "Results" we present our key findings starting with descriptive and later inferential statistics. We expound our findings and their implications in "Discussion". We provide a summary in "Conclusion".

\section{Materials and methods}

\section{Study area}

The study was carried out in the central region of Malawi. The central region has nine administrative districts, which have a comparative advantage for producing maize, the country's staple food (Chirwa 2007). In as much as the whole country trades in maize, the majority of maize traders are situated in the central region (Messina et al. 2017). Second, the region is logistically cost effective to the study since it contains most of the traders and other stakeholders.

\section{Sampling, data and variables}

We assume that the population of traders $(N)$ is sufficiently large but we do not know the variability among traders' performance $(p)$. Following Cochran (1985) p. 75, we assume maximum variability of $(p=0.5)$. We further assumed a desired confidence level of $95 \%$-corresponding to a $z$-value $=1.96$. Further, we used $\pm 10 \%$ level of precision (e). Our sample size is then $n=\frac{Z^{2} p(1-p)}{e^{2}}=96$. To account for uncertainties due to logistics, we adjusted the sample size upwards by $50 \%$ to 144 . At the end of the survey, we had interviewed 172 traders, i.e. 28 more traders. 
Before drawing the sample we obtained a list of markets that are followed by the Ministry of Agriculture and Food Security's Agricultural Statistical Bulletin. From that list, we picked historical central markets-i.e. markets that had consistent price and commodity series. We obtained numbered list of traders in a given market from market authorities and listed them in ascending order. In the case where the market did not have a list of traders, we conducted a linear listing of the traders-usually traders selling maize are arranged in a line and obtaining a list was simply done by obtaining their names and assigning numbers to them. Using the lists, the first trader in the survey was picked using simple random sampling while the second to the $n$th trader was picked using systematic random sampling by counting the next 3 traders-where the number three was chosen arbitrarily. For each of the markets $j=1, \ldots, k$ containing $i=1$, $\ldots, n$ traders, we draw a systematic sample without replacement and calculate a market mean, of say profit or resilience-survivability, as $\bar{y}_{\text {sys }}=\sum y_{i j} / n_{j}$ such that our system-

atic sampling mean is $\bar{Y}=\frac{1}{k} \sum_{j=1}^{k} \bar{y}_{s y s}$. The systematic sampling variance is then calculated as $S^{2}=\frac{1}{k(n-1)} \sum_{i=1}^{n} \sum_{j=1}^{k}\left(y_{i j}-\bar{y}_{j}\right)^{2}$ (Cochran 1985 p. 207).

The key sources of expert and secondary information were the Ministry of Agriculture and Food Security's (MoAFS) Department of Agricultural Planning Services (DAPS), where we obtained information on historical prices using their Agricultural Statistical Bulletin. We also obtained information on gross margins and average prices from the Department of Agricultural Extension Services (DAES). The second prior data source was the Malawi Strategy Support Program (MASSP) of the International Food Policy Research Institute (IFPRI) where we interviewed the IFPRI team of experts. The IFPRI team provided monthly prices summarized in the form of policy briefs (MASSP 2018) and indicated their availability for clarifications. We also interviewed other players in the maize marketing industry such as the National Food Reserve Agency (NFRA) and prominent traders. Results of the sampled markets and their respective sample sizes are summarized in Table 1.

During the study, we also used simple ethnographic data collection techniques namely: participant observation (see Junker 1960) in which we went to the market and observed market transactions to clarify questions and get accustomed to different market environments. The study also used key informant interviews (Adler and Adler 2003) with industry experts where we asked questions about the structure and conduct of the market. This way, we obtained qualitative and quantitative prior information. For instance, we asked different experts about average prices, quantities and by how much the averages might deviate. The information is summarized in Table 2.

\section{Theoretical framework}

Traders in our study act strategically and mostly own micro-enterprises, have capacity constraints. As such, we treat them from a game theoretic perspective (Reny and Perry 2006). To simplify, a trader interacts with other neighbouring traders in a Cournot strategic game (Abbink et al. 2011). All traders trade in a homogeneous commodity i.e. maize. We assume that trader $(i)$ produces output $q_{i}$ while trader (j) produces output $q_{j}$. Thus, for all markets in the sample (see Table 1 ), there exists total market output $Q=q_{1}+\ldots+q_{\mathrm{n}}$ where $q_{i}=a-b p_{i}$ are trader $i$ 's linear demand curves. 
Table 1 Distribution of sampled observations across markets and districts

\begin{tabular}{lllllll}
\hline Market & Districts: & & & & Total \\
\cline { 2 - 7 } & Kasungu & Dowa & Lilongwe & Mchinji & Dedza & \\
\hline Kasungu & 15 & 0 & 0 & 0 & 0 & 15 \\
Chamama & 14 & 0 & 0 & 0 & 0 & 14 \\
Mtunthama & 3 & 0 & 0 & 0 & 0 & 3 \\
Chatoloma & 2 & 0 & 0 & 0 & 0 & 2 \\
Dowa & 0 & 12 & 0 & 0 & 0 & 12 \\
Mponela & 0 & 11 & 0 & 0 & 0 & 11 \\
Madisi & 0 & 12 & 0 & 0 & 0 & 12 \\
Kasiya & 0 & 0 & 10 & 0 & 0 & 10 \\
Lilongwe & 0 & 0 & 21 & 0 & 0 & 21 \\
Mitundu & 0 & 0 & 17 & 0 & 0 & 17 \\
Nkhoma & 0 & 0 & 8 & 0 & 2 & 10 \\
Mchinji & 0 & 0 & 0 & 10 & 0 & 10 \\
Kapiri & 0 & 0 & 0 & 14 & 0 & 14 \\
Chimbiya & 0 & 0 & 0 & 0 & 10 & 10 \\
Bembeke & 0 & 0 & 0 & 0 & 10 & 10 \\
Total & 33 & 37 & 56 & 24 & 22 & 172 \\
\hline
\end{tabular}

We further assume that each trader maximizes their profits. For example, firm $(i)$ maximizes its profits

$$
\max _{i}=p(Q) q_{i}-c_{i\left(q_{i}\right)} \quad i=1, \ldots, n
$$

Thus, for trader $(i)$, profitability is clearly dependent on trader (j)'s output on the market. Thus, assuming that eq. 1 is continuous and twice differentiable, an interior optimum for each trader, the Cournot-Nash equilibrium must satisfy the following first-order necessary conditions

$$
D_{q_{i}} \pi_{i}=p(Q)+p^{\prime}(Q) q_{i}-c_{i}^{\prime}\left(q_{i}\right)=0
$$

The second-order conditions are

$$
D_{q_{i}}^{2} \pi_{i}=2 p^{\prime}(Q)+p^{\prime \prime}(Q) q_{i}-c^{\prime \prime}\left(q_{i}\right)<0, \quad i=1, \ldots, n
$$

Okuguchi (1993) provided axioms namely $p^{\prime}+p^{\prime \prime} q_{i}<0$ and $p^{\prime}<C_{i}^{\prime \prime}$ to ensure that the second-order sufficient conditions are less than zero.

In order to determine how trader $(j)$ might react we should differentiate the firstorder conditions with respect to $q_{j}$. Thus,

$$
f_{i}^{\prime}\left(q_{j}\right)=\frac{D^{2} \pi_{i} / D q_{i}}{D^{2} \pi_{i} / D_{i}^{2}}
$$

Considering that both traders trade in a homogeneous commodity, we assume that the sign for $f_{i}^{\prime}\left(q_{j}\right)$ will be negative implying that the competitor will want to strategically substitute trader $(i)$. In a once off trading occasion, the trade will take the form of a classic Prisoners' Dilemma where the optimal strategy would be to defect. 
Table 2 Key variables used in the analysis and prior elicited information

\begin{tabular}{|c|c|c|c|}
\hline Variable & Description & Prior source & Mean (SD) \\
\hline Maize prices & Prevailing price of maize $(\mathrm{MK} / \mathrm{kg})$ & MOAFS, IFPRI, ADMARC & $35(25)$ \\
\hline Profit & Price Cost Margin (PCM) (MK/kg) & $\begin{array}{l}\text { MoAFS, IFPRI, market } \\
\text { chairperson }\end{array}$ & $25(12)$ \\
\hline Trader is male & Proportion of traders who are male & Observation & $.75(.20)$ \\
\hline $\begin{array}{l}\text { Registered } \\
\text { business }\end{array}$ & Whether business was registered & $\begin{array}{l}\text { MRA, market chairperson, } \\
\text { MCCCl }\end{array}$ & $.20(.10)$ \\
\hline Export licence & Whether the business has an export licence & MCCCl, market chairperson & $.05(.03)$ \\
\hline No. trader & Number of traders in the market & District council, observation & $28(17)$ \\
\hline $\begin{array}{l}\text { Asset } \\
\text { replacement }\end{array}$ & Frequency of asset replacement & - & Flat \\
\hline Search time & $\begin{array}{l}\text { Time spent searching for market information } \\
\text { (minutes) }\end{array}$ & & $120(60)$ \\
\hline No. family & Number of family members in maize business & - & Flat \\
\hline Business age & Age of the business & $\mathrm{MCCCl}$, trader & $5(10)$ \\
\hline Coverage & Geographical coverage of the business & Trader, market chairperson & $15(8)$ \\
\hline No. friends & Number of friends in maize business & - & flat \\
\hline $\begin{array}{l}\text { No. regional } \\
\text { traders }\end{array}$ & Number of regional traders interacted with & Market chairperson & $5(3)$ \\
\hline $\begin{array}{l}\text { No. district } \\
\text { traders }\end{array}$ & Number of district traders interacted with & Market chairperson & $12(5)$ \\
\hline $\begin{array}{l}\text { Experience } \\
\text { broker }\end{array}$ & Experience interacting with brokers (years) & Market chairperson, brokers & $5(6)$ \\
\hline Religion & Religious affiliation of the trader & Market chairperson & \\
\hline Christian Catholic & & & $25(10)$ \\
\hline $\begin{array}{l}\text { Christian } \\
\text { Protestant }\end{array}$ & & & $35(10)$ \\
\hline Islam & & & $10(5)$ \\
\hline African religion & African religion and others & & $5(2)$ \\
\hline Trader tribe & Tribe and mother tongue of the traders & Traders, market chairperson & \\
\hline Chichewa & & & $.74(.12)$ \\
\hline Chiyao & & & $.15(.05)$ \\
\hline Chilomwe & & & $.10(.05)$ \\
\hline Chisena & & & $.01(.01)$ \\
\hline
\end{tabular}

The term mean and standard deviation (SD) are obtained from industry experts

$M O A F S=$ Ministry of Agriculture and Food Security, Malawi Government. The Ministry name changes from time to time $I F P R I=$ International Food Policy Research Institute (Malawi Strategy Support Program) $A D M A R C=$ Agricultural Development and Marketing Corporation. A government parastatal $\mathrm{MCCCl}=$ Malawi Confederation of Chambers of Commerce and Industry. A private sector representative mother body $M R A=$ Malawi Revenue Authority. Malawi's Tax Agency.

Market chairperson/trader $=$ an individual who is elected by fellow traders to coordinate affairs of a given market $G P C M=[($ Sales revenue - Variable costs $) /$ Sales revenue $] \times 100$

Traders do not play one-off stage games. They interact repeatedly. In a repeated game, the output of choice for trader $i$ in time $t$ is given by $q_{i}^{t}=f_{i}\left(q_{j}\right)^{t-1}$ and profits will be $\pi_{i t}=\delta^{t} \pi_{i t}$ where $\delta$ is a discount factor to measure the patience of the trader. The Nash reversion folk theorem states that given a strategy profile in an infinitely repeated game, where the end game reverts to a Nash equilibrium as is the one-off stage game, then each player's strategy is to play a consistent outcome until someone finally defects (see Mas-Collel and Green 1995 pp. 417). That is, with learning effects, market 
outcomes can improve since traders will learn the others' reaction functions and play consistent strategies.

Proposition: Social capital is a parameter that is associated with the trader's profit function. Thus, the accumulation of social capital will affect profitability.

Proof: Considering the traders' first-order conditions and $\omega$, a social capital parameter, we can present the stationarity conditions as

$$
D q_{i}\left[q_{i}\left(\omega_{i}\right), q_{j}\left(\omega_{j}\right)\right]=0
$$

In order to examine the impact of social capital, we take the derivative with respect to $\omega$. That is,

$$
\left(\begin{array}{cc}
D_{q_{i}}^{2} & D_{q_{i}, q_{j}}^{2} \pi_{i} \\
D_{q_{j}, q_{i}}^{2} \pi_{j} & \mathrm{D}_{q_{i}}^{2}
\end{array}\right)\left(\begin{array}{c}
D_{\omega q_{i}} \\
D_{\omega q_{j}}
\end{array}\right)=\left(\begin{array}{c}
\mathrm{D}_{q_{i}, q_{j}}^{2} \pi_{i} \\
0
\end{array}\right), \forall i \neq j .
$$

So using Crammer's rule, the impact of social capital on a firm's performance can be quantified as

$$
\mathrm{D}_{\omega q_{1}}=\frac{\left|\begin{array}{cc}
\mathrm{D}_{q_{i}, \omega}^{2} \pi_{i} & \mathrm{D}_{q_{i}, q_{j}}^{2} \pi_{i} \\
0 & \mathrm{D}_{q_{j}} \pi_{j}
\end{array}\right|}{\left|\begin{array}{ll}
\mathrm{D}_{q_{1}, \omega} \pi_{1} & \mathrm{D}^{2} \pi_{j} \\
\mathrm{D}_{q_{1} q_{j}} \pi_{j} & \mathrm{D}_{q_{j}^{2}}^{2} \pi_{j}
\end{array}\right|} .
$$

It quantifies the effect of a change in social capital on firm's quantity supplied on the market-a direct measure of industry share which is a function of arguments from profits from firm 1 and 2 and their respective reaction functions. We learn two things from this quantity. First, if the traders only met once, then it would make sense for them to use defective strategies, making the $D_{q 1, \omega}^{2} \pi_{1}$ quantity negative as it would make one firm take advantage to maximize its own profit at the expense of the other. Resultant, the other firm would also play a similar move. Second, if traders would repeatedly interact in the market, and the equilibrium is mutually beneficial (Dal Bó and Fréchette 2011), there could be an evolution of cooperation which could foster learning effects and eventually firm and market performance would increase. It would be optimal for players to play cooperatively and it would be punishable to play defective strategies. Although this seems intuitive, in real life, less optimal outcomes are also possible as people make mistakes. In our study, we do not preclude the existence of a trader making a mistake in decision-making.

However, as traders keep interacting and learning from each other, it is expected that they would adopt strategies that work in improving their businesses and abandon the strategies that do not work. Nowak (2006) and Smith (1988) call a strategy that achieves this and ultimately dominates an Evolutionary Stable Strategy (ESS). In this study, traders that tend to play sub-optimal strategies will be left out by the process of evolution and they will go bankrupt. Further, Hamilton (1964) suggested that natural selection would most certainly favour cooperation and altruistic behaviour in more genetically related individuals. So, in our context, we assume that businesses would perform much better among related individuals and friends. That is, if a closely related individuals business is falling apart, a relative or a friend they interact with could bail 
them out in the form of a loan or a mere handout. However, we also take note of Levine et al. (2014) observation that ethnic diversity could also lead to better market outcomes. We thus, use different indicators of cooperation in traders interactions, namely (1) kin selection, where individual traders interact more with genetically related individuals; (2) group selection, where individuals would interact more among friends doing similar kind of trade and; (3) direct reciprocity where at first, we observe how firms run as sole trading entities perform and survive. We also group the traders in ethnicity terms to observe how one ethnic group operates against another in direct reciprocity (Trivers 1971).

\section{Estimation}

Considering that we used two sources of data namely trader survey and key informant interviews, it is ideal to bring the two data sets together in the process of drawing inference about the population parameters. For a start, our key informants i.e. key industry experts, few handpicked traders and government personnel informed us about the distribution of the parameters. We use this prior knowledge to complement the survey data in the estimation process of the posterior distribution of parameters and their $95 \%$ credible intervals. We thus use Bayesian normal regression techniques to assess the effects of social capital, on firm profitability and resilience. Our basic regression framework is presented as

$$
Y_{i j d}=\beta_{i j d} X+\gamma_{j}+\delta_{d}+\lambda_{t}+\epsilon_{i j d}
$$

where $Y$ is the $n \times 1$ vector of natural logarithm of profits of trader or firm $i$ in market $j$ and district $d$. The variable $X_{i j d}$ is an $n \times m$ vector of independent variables that explain the variation in $Y_{i j d}$. The quantity $\beta_{i j d}$ is an $m \times 1$ vector of unknown parameters of the explanatory variables, $\gamma_{j}$ is an unknown market-specific fixed effect while $\delta_{d}$ and $\lambda$ are a district and seasonal specific fixed effect.

During data collection period, we obtained prior information on the historical estimates, behaviour and structure of the market. This prior information can be useful in estimating the model parameters and reducing uncertainty. To further reduce the level of uncertainty, we use Bayes Model Averaging (BMA) estimator (Hoeting et al. 1999) with market- and district-specific fixed effects. Considering the lack of extensive literature on small businesses in Malawi, building an accurate model of business profitability in the context of geographic, social institutional and physical capital could be challenging. Thus, given the context, there are many, i.e. the model space is $M=2^{m}$ where $m$ $\in M$, competing models that can be estimated from the given variables. Therefore, fitting one Ordinary Least Squares regression model could result in high measurement and specification errors when expert knowledge is limited and sample sizes are small (Genell et al. 2010). BMA fits a regression of the form

$$
Y_{i j d}=\beta_{i j d}(X-\bar{X})+\gamma_{j}+\delta_{d}+\lambda_{t}+\epsilon_{i j d}
$$

where the unconditional BMA results' $\beta_{i j d}$ are weighted average parameters conditional on each of the competing models in the model space, i.e. $m \in M$ (Hoeting et al. 1999; Laffineur et al. 2017). Thus, the BMA estimator is 


$$
\hat{\beta}_{i j d}=E\left(\beta_{i j d} \mid Y_{i j d}\right)=\sum_{m=1}^{M} \tau_{m} \hat{\beta}_{m}
$$

Using Bayes' theorem, we estimate the posterior probability distribution as

$$
\tau_{m}=p(M \mid \text { Data })=\frac{P\left(M_{m}\right) \times p\left(\text { Data } \mid M_{m}\right)}{\int_{m=1}^{2^{m}} P\left(M_{m}\right) \times p\left(\text { Data } \mid M_{m}\right)}
$$

such that $p\left(M_{m}\right)$ is the prior probability distribution of model $m$ while $p\left(\right.$ Data $\left.\mid M_{m}\right)$ is the marginal likelihood distribution of the data given the model $M_{m}$ where the model space is $M$ such that $m \in M$ (Madigan and Raftery 1994; Laffineur et al. 2017). We use $\mathrm{R}$ statistical package BAS (Bayesian Variable Selection and Model Averaging using Adaptive Sampling) - which samples the models without replacement and outperforms Markov Chain Monte Carlo frameworks (Clyde et al. 2011) to estimate the final posterior parameters.

\section{Industry structure}

We used the Herfindahl- Hirschmann Index (HHI) to assess market concentration. The HHI assesses the structure of the market through the lenses of market competitiveness by measuring the size of the firm relative to the size of the industry. Using two indicators namely value of operating capital and volume of commodities that the firm handles per month, we computed the HHI as

$$
H H I=\sum_{i=1}^{n} s_{i}^{2} \text { where } s_{i}=1 / N
$$

where $N$ is the total number of firms in the industry. When the HHI is 0.01 or less, then the market is competitive; when $\mathrm{HHI}$ is 0.15 it is unconcentrated; when $\mathrm{HHI}$ is between 0.15 and 0.25 , the market is moderately concentrated while an HHI of 0.25 and above signifies a concentrated industry. We estimate market, district and regional $\mathrm{HHI}$ indicators. However, in the regression estimation, we use the log of the share as an indicator of industry size.

As a qualitative measure of industry size, we used a count of traders in the market. A larger number of traders was considered to be a competitive market while when there are very few traders, then the market is less competitive.

\section{Results}

\section{Descriptive statistics}

Table 2 summarizes variable descriptions and results of the prior expert information elicited through the qualitative data collection techniques. The data obtained complements the survey data estimates and are later used in the Bayesian estimation. In general, results closely match the data such that we can safely deduce that the prior has similar distributions.

Table 3 summarizes results of the descriptive statistics of key variables that are used in the study. The study's dependent variables are business profitability and business resilience. The average profit of the maize business was MK30 per kilogramme. Results show that $91 \%$ of the traders were male ageing between 20 and 71 years old. In addition, when asked about whether they set prices, 39\% of traders reported that they discuss with about 10 colleagues setting market prices. Traders also indicated that it took 14 min to get to the market from their home. Results also indicate that $9 \%$ have 
Table 3 Descriptive statistics of key variables used in the study

\begin{tabular}{|c|c|c|c|c|c|}
\hline Variable & No. of traders & Mean & SD. & Min & Max \\
\hline Log of profit & 172 & 4.9 & 2.178 & .613 & 7.133 \\
\hline Age of business & 172 & 7.263 & 5.706 & 1 & 28 \\
\hline Age of trader & 172 & 34.127 & 9.043 & 20 & 71 \\
\hline Trader is male & 172 & .919 & .274 & 0 & 1 \\
\hline Trader dictates prices & 172 & .39 & .488 & 0 & 1 \\
\hline Trader interaction (count) & 172 & 9.906 & 9.544 & 1 & 90 \\
\hline Distance to nearest market (log mins) & 172 & 2.674 & 1.112 & 0 & 4.787 \\
\hline Trader has an export licence & 172 & .093 & .291 & 0 & 1 \\
\hline Industry size (log) & 172 & 2.187 & .98 & 2 & 4.605 \\
\hline \multicolumn{6}{|l|}{ Measures of social capital } \\
\hline \multicolumn{6}{|l|}{ Religion of trader } \\
\hline Roman Catholic & 172 & .152 & .781 & 0 & 1 \\
\hline Christian Protestant & 172 & .651 & .477 & 0 & 1 \\
\hline Islam & 172 & .14 & .347 & 0 & 1 \\
\hline African Traditional Religion & 172 & .006 & .076 & 0 & 1 \\
\hline None & 172 & .041 & .198 & 0 & 1 \\
\hline Other religions & 172 & .012 & .107 & 0 & 1 \\
\hline \multicolumn{6}{|l|}{ Trader's mother tongue } \\
\hline Chiyawo & 172 & .041 & .198 & 0 & 1 \\
\hline Chilomwe & 172 & .035 & .184 & 0 & 1 \\
\hline Chisena & 172 & .006 & .076 & 0 & 1 \\
\hline No. family members in business & 172 & 1.285 & 1.446 & 1 & 8 \\
\hline No. close friends in business & 172 & 5.622 & 6.373 & 0 & 40 \\
\hline Contacts with regional traders & 172 & 12.32 & 12.15 & 0 & 100 \\
\hline Contacts with distant traders & 172 & 8.564 & 9.066 & 0 & 60 \\
\hline Experience (years) with brokers & 172 & 4.378 & 2.452 & 1 & 15 \\
\hline Business was registered & 172 & .244 & .43 & 0 & 1 \\
\hline
\end{tabular}

an export licence. Further, traders reported that a market contained between 7 and 54 maize traders.

Considering the three dimensions of social capital namely (1) closeness with family members and ethnically similar individuals; (2) closeness with traders in the vicinity and (3) interaction with distant traders. On similarity between individuals, we used tribe and religion as indicators closeness. Results indicate that $15 \%$ of the traders were Roman Catholic; 65\% were Protestant; 14\% Muslim and 5\% either had no religion or practised other religions. Results further show that $92 \%$ of traders are of the Chewa tribe while $4 \%$ are Yao and Lomwe, respectively. Less than $1 \%$ of the traders are of the Sena tribe. On average, one member of the family, usually (self) participated in maize trade with a range of 7 members. The average trader reported that they had 6 close friends who they interacted closely within the maize trading business.

Results indicate that a trader interacted most with 12 traders within the region and 9 distant traders. Results also show that a trader interacted with 4 brokers in the market.

Whether the business was registered or not is of fundamental importance in determining performance and resilience. Results indicate that $78 \%$ of the business were not 
registered. The mean age for registered businesses was 9.32 years with a standard deviation of 0.89 years while for unregistered businesses was 6.58 years with a standard error of 0.41 years. Though the samples are unequal, a $t$ test $(t=3)$ indicates that registered businesses tend to stay 3 years longer than unregistered businesses. These results are statistically significant at $1 \%$ significance level.

\section{Industry structure}

Table 4 summarizes results of the HHI. Of note, the value of the HHI decreases as we move from an individual market to district and eventually regional level measure of concentration. Results indicate that at the local market, the level of market concentration is $47 \%$. This HHI value is greater than $25 \%$ which indicates that at the market level, maize markets do not operate in perfect competition. Thus, in order to analyse the data at the market level, a model that accounts for strategic interactions among traders is necessary. Similarly, the district level HHI is $28 \%$, computed by accounting for all markets within the district in question, is also larger than the $28 \%$ value-indicating that the maize market is also concentrated at the district level.

Noteworthy, Kapiri market in Mchinji District and Bembeke market in Dedza District had the lowest HHI equal to 0.205 and 0.208 , respectively. The HHI values fall within the range of 0.15 and 0.25 which indicates that these markets were moderately concentrated-meaning that the small firms in the market were altogether operating in oligopolistic competition. Thus, the Cournot theoretical framework is appropriate for analysing strategic behaviour of the firms. Market level HHIs for the rest of the markets are above 0.25 and are unambiguously concentrated. Importantly, markets that had lower concentration levels lead to much lower concentration values at the district level. Of note, Lilongwe District markets had higher levels of concentration at the market

Table 4 Measures of market concentration using the Herfindahl Index

\begin{tabular}{lllllll}
\hline District & Market & $N$ & Market HI & District HI & PCM & \$lepsilon_i\$ \\
\hline Kasungu & Kasungu & 15 & .370 & .285 & .059 & .070 \\
& Chamama & 14 & .843 & .285 & .280 & .424 \\
& Nkhamenya & 3 & .557 & .285 & .147 & .002 \\
\multirow{5}{*}{ Dowa } & Chatoloma & 2 & .966 & .285 & .150 & .331 \\
& Dowa & 12 & .452 & .372 & .230 & .055 \\
& Mponela & 11 & .761 & .372 & .500 & .248 \\
\multirow{3}{*}{ Lilongwe } & Madisi & 12 & .259 & .372 & .235 & .265 \\
& Kasiya & 10 & .430 & .215 & .265 & .049 \\
& Lilongwe & 21 & .505 & .215 & .190 & .262 \\
& Mitundu & 17 & .619 & .215 & .328 & .224 \\
\multirow{3}{*}{ Mchinji } & Nkhoma & 10 & .451 & .215 & .328 & .128 \\
& Mchinji & 10 & .419 & .327 & .205 & .525 \\
Dedza & Kapiri & 14 & .205 & .327 & .285 & .753 \\
& Chimbiya & 10 & .258 & .192 & .310 & .059 \\
Market & Bembeke & 10 & .208 & .192 & .165 & .014 \\
\hline PCM & 10 & & & & \\
\hline
\end{tabular}

$\mathrm{PCM}=\left[(\right.$ Sales revenue - Variable costs)/Sales revenue $] s_{i}=$ market share calculated as cumulative maize quantity supplied by a trader divided by total quantity of maize supplied by all traders. $\epsilon_{i}=P C M_{i} / s_{i}$ is the price elasticity of demand. 
level, but when the analysis was moved to the district level, the industry became moderately concentrated. At regional level i.e. the full sample, the data shows that the industry is in perfect competition. That is, it has HHI values between 0.15 and 0.25.

Results in Table 4 also present price-cost margins (PCM) - a ratio of the difference between sales and variable costs by sales (Aiginger 1996). Results indicate that traders located in larger trading centres have lower PCM. For instance, Kasungu town market had PCM of $6 \%$ while Mponela township had 5\%. Nkhoma market, a trading centre just outside Lilongwe city, had the highest PCM of 33\%. Overall, the average industry PCM was $19 \%$.

Generally, the price elasticity of demand for maize across the markets was less than unitary i.e. $1 \%$ change in the price of maize would result in a less than unitary change in the quantity of maize demanded holding other factors constant.

\section{Behaviour among traders}

As an indicator of social capital, trader norms and behaviour, we assessed traders' perceptions regarding how they relate with brokers and other traders (Table 5). Results indicate that there is a general consensus that brokers have better access to market information. We failed to reject the hypothesis that there is a difference in perception between registered traders and unregistered traders. Further, respondents were neutral when asked about whether the broker acts as their guarantor or not. Results for this question were also not statistically significant implying that traders were not aware that a broker can sometimes act as a guarantor on some loans. Further, results indicate a general agreement that the broker has more contacts.

We also find a general consensus that brokers identify good quality maize. There was also an agreement that sometimes traders have no choice but to sell through brokers. There was also a consensus that brokers give business advice. Over $42 \%$ of traders in the sample agree that it is less costly to work with brokers. However, when disaggregated by business registration, we find that unregistered traders are more agreeable to the statement than registered traders who were more neutral. Registered traders neutrality might indicate that registered traders incur some costs making it difficult judging right away whether they agree or disagree.

Further, $34 \%$ of the respondents indicated that they agree that they trade with traders and brokers that they know well. When disaggregated by business registration, we find that registered businesses formed a consensus disagreeing with the statement. The difference in opinion was statistically significant at $5 \%$. This implies that traders that are registered are more likely to trade with traders or brokers that are less familiar to them. Another 55\% of respondents reported that they know the market well enough. There is a consensus that brokers cheat on prices. Further, $51 \%$ of the respondents do not consult brokers because they want to save commission fees. Further, $35 \%$ of the traders in the sample reported that they do not need a quick transaction to require a broker.

\section{The role of social capital in determining business performance}

Table 6 summarizes results of the Bayesian regression analysis of the effect of social capital on business profitability. The table presents three models. First, a Bayesian model with informative prior where we report posterior means, standard deviations 
Table 5 Perceptions of traders' interactions with brokers and other traders. Percentages are reported in the Likert Scale and $t$ test is used to assess differences in perceptions between firms that were registered and those that were not

\begin{tabular}{|c|c|c|c|c|c|c|c|c|c|}
\hline \multirow[t]{2}{*}{ Statement } & \multirow{2}{*}{$\begin{array}{l}\text { Strongly } \\
\text { disagree } \\
\text { (1) }\end{array}$} & \multirow{2}{*}{$\begin{array}{l}\text { Disagree } \\
\text { (2) }\end{array}$} & \multirow{2}{*}{$\begin{array}{l}\text { Neutral } \\
\text { (3) }\end{array}$} & \multirow{2}{*}{$\begin{array}{l}\text { Agree } \\
\text { (4) }\end{array}$} & \multirow{2}{*}{$\begin{array}{l}\text { Strongly } \\
\text { agree } \\
\text { (5) }\end{array}$} & \multicolumn{4}{|c|}{ Firm registration } \\
\hline & & & & & & Unregistered & Registered & Difference & $t$ test \\
\hline $\begin{array}{l}\text { Broker has better } \\
\text { access to market } \\
\text { information }\end{array}$ & 2 & 2 & 10 & 49 & 35 & 4.15 & 4.07 & .08 & .53 \\
\hline $\begin{array}{l}\text { Broker acts as } \\
\text { guarantor }\end{array}$ & 2 & 15 & 35 & 43 & 5 & 3.33 & 3.33 & 0 & 0 \\
\hline $\begin{array}{l}\text { Broker has more } \\
\text { contacts }\end{array}$ & 1 & 2 & 14 & 62 & 22 & 4.03 & 3.9 & .13 & 1.03 \\
\hline $\begin{array}{l}\text { Broker identifies } \\
\text { good quality }\end{array}$ & 2 & 11 & 20 & 49 & 19 & 3.72 & 3.69 & .03 & .19 \\
\hline I have no choice & 3 & 21 & 38 & 32 & 6 & .23 & 2.93 & .3 & 1.83 \\
\hline $\begin{array}{l}\text { Broker gives } \\
\text { business advice }\end{array}$ & 3 & 21 & 24 & 45 & 5 & 3.35 & 3.19 & .23 & 1.31 \\
\hline $\begin{array}{l}\text { It's less costly to } \\
\text { work with broker }\end{array}$ & 4 & 16 & 31 & 42 & 6 & 3.42 & 3 & .42 & 2.5 \\
\hline $\begin{array}{l}\text { I trade with } \\
\text { partners I know } \\
\text { well }\end{array}$ & 4 & 30 & 26 & 34 & 6 & 3.18 & 2.74 & .44 & 2.47 \\
\hline $\begin{array}{l}\text { I know the } \\
\text { market well } \\
\text { enough }\end{array}$ & 1 & 1 & 19 & 55 & 24 & 4.02 & 3.93 & .09 & .71 \\
\hline $\begin{array}{l}\text { Brokers cheat on } \\
\text { prices }\end{array}$ & 3 & 2 & 12 & 58 & 24 & 3.99 & 3.98 & .02 & .11 \\
\hline $\begin{array}{l}\text { I want to save } \\
\text { commission fees }\end{array}$ & 1 & 8 & 35 & 51 & 5 & 3.5 & 3.43 & .10 & .75 \\
\hline $\begin{array}{l}\text { I do not need a } \\
\text { quick transaction }\end{array}$ & 5 & 28 & 35 & 27 & 4 & 3.01 & 2.83 & .18 & 1.06 \\
\hline $\begin{array}{l}\text { I had a } \\
\text { disagreement } \\
\text { with the broker }\end{array}$ & 1 & 10 & 17 & 53 & 19 & 3.77 & 3.81 & -.03 & -.20 \\
\hline
\end{tabular}

and the probability that the posterior mean is not equal to zero i.e. $p(\beta \neq 0)$.The model is presented in columns 1 to 3 . Second, we present a Bayesian model with reference priors in columns 4 to 6 . This model uses information from the sample to compute posterior probabilities. In the event that our informative priors are misleading, this model acts as an objective robustness check. Third, we used an Ordinary Least Squares regression model with bootstrapped standard errors replicated 1000 times in columns 7 to 9. Using a frequentist approach with highly conservative standard errors compared to those produced by normal OLS ensures that the precision of our estimates is based on actual variation in the information from the sample and not just chance. The bootstrapped model also shows the level of bias associated with the resampling. In the informative prior model, we used a normally distributed prior with mean 12.65 and the model variance from the sample to estimate the posterior distribution of parameters using 20000 Monte-Carlo Markov Chain (MCMC) simulations.

Results indicate that registered businesses were $83 \%$ more profitable than unregistered ones. Further, traders that possessed export licences were twice more profitable. If a trader ran other businesses apart from the current grain trading, it resulted in $4 \%$ more profits in the maize grain trading business. Results further show that traders who 


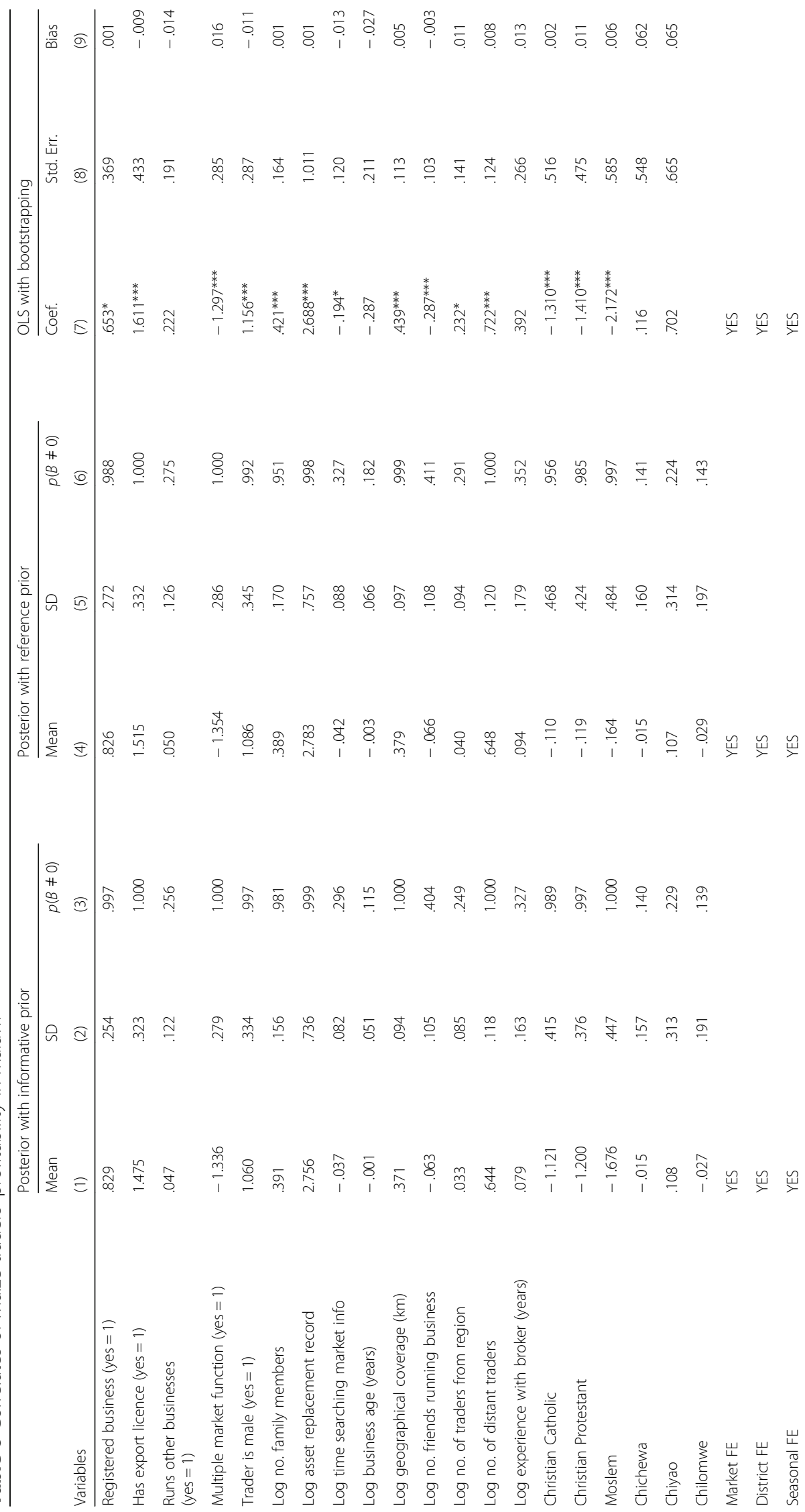




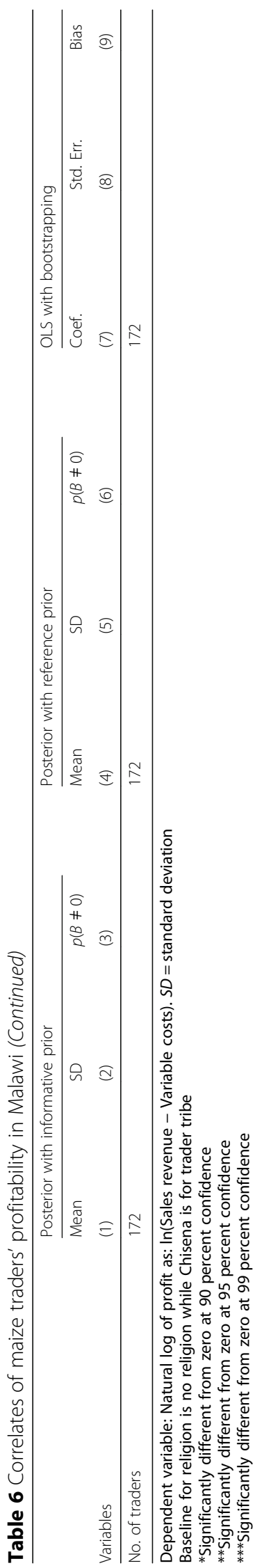


Table 7 Determinants of maize traders' business resilience in Malawi

\begin{tabular}{|c|c|c|c|c|c|c|c|c|c|}
\hline & \multicolumn{3}{|c|}{$\begin{array}{l}\text { Posterior with } \\
\text { informative prior }\end{array}$} & \multicolumn{3}{|c|}{$\begin{array}{l}\text { Posterior with } \\
\text { reference prior }\end{array}$} & \multicolumn{3}{|c|}{ OLS with bootstrapping } \\
\hline & Mean & SD & $p(B \neq 0)$ & Mean & SD & $p(B \neq 0)$ & Coef. & Std. err. & Bias \\
\hline Registered business & .011 & .043 & .188 & .009 & .038 & .126 & .128 & .099 & -.008 \\
\hline Has export licence & .092 & .102 & .598 & .068 & .100 & .408 & .162 & .124 & .002 \\
\hline Runs other businesses & -.135 & .063 & .954 & -.106 & .080 & .749 & $-.215^{* * *}$ & .069 & .001 \\
\hline Engages in value addition & .238 & .088 & .993 & .249 & .099 & .966 & .174 & .114 & -.007 \\
\hline Trader is male & -.308 & .102 & .997 & -.310 & .115 & .978 & $-.349^{* *}$ & .165 & -.009 \\
\hline $\begin{array}{l}\text { Log no. of family members in } \\
\text { business }\end{array}$ & -.001 & .014 & .086 & .000 & .011 & .060 & -.040 & .052 & .002 \\
\hline Log asset replacement record & -.529 & .256 & .948 & -.457 & .318 & .790 & $-.681^{* * *}$ & .238 & -.057 \\
\hline $\begin{array}{l}\text { Log time spent searching for } \\
\text { market info }\end{array}$ & -.107 & .032 & .998 & -.113 & .033 & .996 & $-.094^{* *}$ & .042 & -.004 \\
\hline $\begin{array}{l}\text { Log of geographical coverage } \\
(\mathrm{km}) \text { radius }\end{array}$ & .114 & .031 & 1.000 & .119 & .032 & .998 & $.125^{* * *}$ & .035 & .005 \\
\hline Log no. of district but distant traders & .004 & .017 & .145 & .003 & .016 & .101 & -.009 & .039 & .004 \\
\hline Log experience with broker (years) & .558 & .060 & 1.000 & .587 & .063 & 1.000 & $.594^{* * *}$ & .084 & .002 \\
\hline Log no. of friends running business & .143 & .035 & 1.000 & .148 & .036 & 1.000 & $.185^{* * *}$ & .045 & .895 \\
\hline $\begin{array}{l}\text { Log no. of traders from the } \\
\text { same region }\end{array}$ & .120 & .037 & .998 & .128 & .039 & .994 & $.109^{* * *}$ & .041 & -.001 \\
\hline Christian Catholic & -.067 & .080 & .559 & -.044 & .073 & .362 & -.113 & .131 & .009 \\
\hline Christian Protestant & -.001 & .034 & .152 & .001 & .024 & .089 & -.011 & .110 & .003 \\
\hline Moslem & .029 & .067 & .284 & .014 & .048 & .147 & .205 & .153 & .007 \\
\hline Chichewa & -.004 & .036 & .102 & -.003 & .030 & .067 & -.011 & .164 & .002 \\
\hline Chiyao & .003 & .049 & .102 & .003 & .041 & .069 & -.173 & .244 & .010 \\
\hline Chilomwe & .004 & .046 & .097 & .002 & .038 & .064 & & & \\
\hline Market FE & YES & & & YES & & & YES & & \\
\hline District FE & YES & & & YES & & & YES & & \\
\hline Seasonal FE & YES & & & YES & & & YES & & \\
\hline No. of traders & 172 & & & 172 & & & 172 & & \\
\hline
\end{tabular}

Dependent variable is log of age of the business $S D=$ standard deviation

Baseline for religion is no religion while Chisena is for trader tribe

*Significantly different from zero at $90 \%$ confidence

**Significantly different from zero at $95 \%$ confidence

***Significantly different from zero at $99 \%$ confidence

participated in many marketing functions had profits, which were lower by a factor of 1.3 than traders who consistently performed one marketing function. Traders that were combining multiple functions were mostly small and itinerant with capacity and credit constraints.

We also find that male traders were twice more profitable than female-ran businesses. The number of close family relatives is associated with $40 \%$ more profits. We found that traders who were innovative in changing assets and trying new technologies during trading realized 37\% profitable businesses. Results indicate that the larger the geographical coverage of the business, the more profitable the business i.e. $1 \%$ increase in geographical coverage resulted is $36 \%$ increase in profits. As far as social capital is concerned, we found that the more the trader interacts with traders within the same district but from other distant markets, the more profitable the business is $-1 \%$ 
increase in interactions resulted in $63 \%$ increase in profits. We found higher posterior probabilities that the other measures of social capital such as religion and tribe of the trader have significant effects on profitability.

\section{The role of social capital in business resilience}

Taking age of the business as an indicator of business survivability and resilience (Atmadja et al. 2016), in Table 7 we estimated a model of key success factors of business resilience. We used a normally distributed prior with mean 1.6 and the model variance from the sample to estimate the posterior distribution of parameters using 20000 Monte-Carlo Markov Chain (MCMC) simulations.

Results of the BMA regression model indicate that if a trader has an export licence, it is associated with $9 \%$ increase in business resilience. Further, if the business holds other forms of business apart from grain trading, it is associated with a 15\% increase in business resilience. Traders that engage in multiple marketing functions are associated with $11 \%$ increase in profitability. A male trader is associated with $30 \%$ reduction in business resilience. Traders that often replace assets and actively innovate are associated with $11 \%$ increase in business resilience. Traders that spent more time searching for market information are associated with a 53\% reduction in business resilience. Traders that have a wide geographical coverage are associated with $11 \%$ increase in business resilience. In addition, a $1 \%$ increase in friends running grain trading business results in $14 \%$ increase in business resilience. Further, a $1 \%$ increase in experience with brokers results in $56 \%$ increase in business resilience. When the trader increases interactions with distant traders within the region by $1 \%$, business resilience increases by $12 \%$.

\section{Discussion}

In this study we analysed effects of social capital, industry size and firm performance in the maize sub-sector in Malawi. Our results explain three important findings. First, trader and industry characteristics shape business performance and resilience. Second, the complex nature of business performance and resilience can be explained by unpacking trader characteristics, closeness and wider social interactions.

Our results show that trader and industry characteristics influence profitability and resilience of traders businesses in the maize subsector. First, we found that registered traders were more profitable than unregistered ones. For example, in order for firms to sell to large agencies such as the National Food Reserve Agency (NFRA), they are required to register their businesses. Having a registered business therefore guarantees that the trader can access most lucrative markets (McKenzie and Sakho 2010). On the other hand, unregistered businesses tend to have a narrow base for expanding their business and profitability as they are usually credit constrained-this observation is consistent with Fafchamps and Minten (2001) who found a positive association between formality and performance in Brazil.

We found that at the market level, traders behave in an oligopolistic manner but as one expands to the district and regional levels, the market becomes more competitive. This observation is derived directly from our theoretical model. It is usual to find traders who know each other at the market level. Traders at market level form committees of traders that traded in common commodities. Pricing, threats of punishment and 
trader welfare issues are usually discussed in such groups. This kind of organization could lead to possibilities for collusion (Varian 2014; Mas-Collel and Green 1995). Our results are in stark contrast with (Cai and Szeidl 2016) who found that when firms interact, performance increases. However, their finding was based on a sample that had larger businesses while this study was based on a sample of smaller businesses. Noteworthy, in support of our result, Levine et al. (2014) explain that when firms interact, it leads to collusion, which might end up creating price bubbles that eventually depress industry profits. Based on our findings, we subscribe to Levine et al. (2014)'s explanation that at community market, where traders know each other, they can collude to set prices and therefore create price bubbles which might eventually lower community welfare as consumers would be buying an inefficiently priced maize grain. Of note, in Zambia, Sitko et al. (2018) found that market entry of bigger traders increased market performance by decreasing market prices through improved market information channels and high levels of investment.

We find that social capital exerts influence in shaping business resilience. For instance, results show that traders operating within the same market and district experience an increase in business resilience. We also find that close ties with family members when running the business encourages business resilience. Our results are in agreement with the findings of Islam et al. (2018); Liu and Li (2018); Madigan and Raftery (1994) who found that social capital and business performance and resilience are highly correlated. Our results are not in agreement with Portes (2014) who indicated that such closeness might reduce the business into a large family safety net on which family members use the firm's resources to the detriment of the business performance. Rather, we find that traders who interact a lot with friends and distant traders have more resilient businesses.

Our results support the narrative that social capital leads to businesses that are more resilient, they also provide support for business performance. We find strong posterior probabilities that the association between firm performance and closeness with friends, religiously affiliated and ethnically close traders in the maize business is not equal to zero. Our results also strongly support other notions of social capital such as the number of family members in the business. Family members, as Portes (2014) observed would assist in supporting the business with capital and also providing human resources. This might explain the positive outcomes.

To sum up, results present evidence that long term interaction among traders leads to resilient businesses. Secondly, interactions among closely related traders such as family members, and friends lead to more resilient businesses. From the theoretical framework, the result that close ties with family and friends and increased interaction among traders is highly suggestive of both group and kin selection. As Nowak (2006) put it, natural selection mostly favours some level of altruistic cooperation among genetically related individuals. Evidenced by the significant positive association between family relatedness and trader's profitability, the Hamiltonian rule Hamilton (1964) would lead us to a conclusion that the relatedness we view in the results outweighs its altruistic cost such that the result is a positive firm performance for family members. 


\section{Conclusion}

This study assessed effects of social capital, industry structure on performance and resilience of the firm. Results show that characteristics of the industry namely industry size, market concentration, proportion of registered firms, and proportions of firms having export licences affect both firm performance and resilience. Second, results indicate that ethnically close traders operating within the same area tend to have more productive businesses. In evolutionary game theory, this suggests strong group and kin selection. On the other hand, results showed that group selection prevails as a dominant strategy in building business resilience as close association with friends in the business led to a more resilient business. In order to foster better business performance and resilience, efforts should be put in place to account for social capital arrangements and industry characteristics.

\section{Acknowledgements}

The authors would like to acknowledge Prof. Dr. Dr. h.c. Joachim von Braun for his guidance during the development of this study; Dr. Nicolas Gerber for discussing the data collection tools, the enumerators and traders who voluntarily participated during the data collection period. The authors also acknowledge the anonymous reviewers for their work.

\section{About the authors}

Henry Kankwamba is an economist who has more than five years of experience in agricultural research and policy analysis. He has worked with Malawi's Lilongwe University of Agriculture and Natural Resources as a lecturer, the International Food Policy Research Institute as a research analyst, the World Bank Group and the International Maize and Wheat Improvement Center in various capacities. He is currently pursuing his Doctoral research at the University of Bonn's Center for Development Research (ZEF) under supervision of Prof. Dr. Dr. hc. Joachim Von Braun. Dr Lukas Kornher obtained his PhD from the University of Bonn in 2015. He has extensive work experience in food price volatility and markets in general. He is currently working at the University of Bonn's Center for Development Research (ZEF) as the Coordinator of the Food Monitor Project and Senior Research Fellow. He previously worked at the University of Kiel as a Post-Doctoral Researcher.

\section{Authors' contributions}

HK originated the idea, analysed the data and wrote the first draft. LK proofread the draft, modified technical aspects and discussion of results. Both authors read and approved the final manuscript.

Funding

Funding for the study was provided by the German Academic Exchange Services (DAAD) and Foundation Fiat Panis.

\section{Availability of data and materials}

The authors declare that data shall be provided upon request.

\section{Ethics approval and consent to participate}

An ethical clearance certificate was obtained from the University of Bonn. All participants were asked for their consent to participate in the survey.

\section{Consent for publication}

The authors give consent for publication.

\section{Competing interests}

The authors declare that they have no competing interest.

\section{Author details}

'Department of Agricultural and Applied Economics, Lilongwe University of Agriculture and Natural Resources (LUANAR), Lilongwe, Malawi. ${ }^{2}$ Center for Development Research (ZEF), University of Bonn, Genscherallee 3, 53113 Bonn, Germany.

Received: 13 December 2018 Accepted: 28 June 2019

Published online: 01 August 2019

\section{References}

Abbink K, Jayne TS, Moller LC (2011) The relevance of a rules-based maize marketing policy: an experimental case study of Zambia. J Dev Stud 47(2):207-230

Adler PA, Adler P (2003) The reluctant respondent. Inside interviewing: new lenses, new concerns, pp 153-173

Aiginger K (1996) Confronting the implications of the Cournot model with industry and firm data. Small Bus Econ 8(5):365378

Asiaei K, Jusoh R (2015) A multidimensional view of intellectual capital: the impact on organizational performance. Manag Decis 53(3):668-697 
Atmadja AS, Su JJ, Sharma P (2016) Examining the impact of microfinance on microenterprise performance (implications for women-owned microenterprises in Indonesia). Int J Soc Econ 43(10):962-981

Cai J, Szeidl A (2016) Interfirm relationships and business performance. Q J Econ 133(3):1229-1282

Chirwa EW (2007) Sources of technical efficiency among smallholder maize farmers in southern Malawi. African Portal. https://www.africaportal.org/publications/sources-of-technical-efficiency-among-smallholder-maize-farmers-in-southernmalawi/, Accessed 26 Mar 2019

Clyde MA, Ghosh J, Littman ML (2011) Bayesian adaptive sampling for variable selection and model averaging. J Comput Graph Stat 20(1):80-101

Cochran WG (1985) Sampling Techniques. Wiley, New York

Dal Bó P, Fréchette GR (2011) The evolution of cooperation in infinitely repeated games: Experimental evidence. Am Econ Rev 101(1):411-429

de Oliveira S, Nisbett RE (2018) Demographically diverse crowds are typically not much wiser than homogeneous crowds. Proc Natl Acad Sci 115(9):2066-2071

Fafchamps M, Minten B (2001) Social capital and agricultural trade. Am J Agric Econ 83(3):680-685

Gabre-Madhin EZ (2001) Market institutions, transaction costs, and social capital in the Ethiopian grain market. Intl Food Policy Res Inst 124

García-Villaverde PM, Rodrigo-Alarcón J, Ruiz-Ortega MJ, Parra-Requena G (2018) The role of knowledge absorptive capacity on the relationship between cognitive social capital and entrepreneurial orientation. J Knowl Manag

Genell A, Nemes S, Steineck G, Dickman PW (2010) Model selection in medical research: a simulation study comparing Bayesian model averaging and stepwise regression. BMC Med Res Method 10(1):108

Hamilton WD (1964) The genetical evolution of social behaviour. ii. J Theor Biol 7(1):17-52

Hayami Y (2009) Social capital, human capital and the community mechanism: Toward a conceptual framework for economists. J Dev Stud 45(1):96-123

Hoeting JA, Madigan D, Raftery AE, Volinsky CT (1999) Bayesian model averaging: a tutorial. In: Statistical science, pp 382-401

Islam MM, Habes EM, Alam MM (2018) The usage and social capital of mobile phones and their effect on the performance of microenterprise: An empirical study. Technol Forecast Soc Chang 132:156-164

Junker BH (1960) Field work: an introduction to the social sciences. University of Chicago Press

Laffineur C, Barbosa SD, Fayolle A, Nziali E (2017) Active labor market programs effects on entrepreneurship and unemployment. Small Bus Econ 49(4):889-918

Levine SS, Apfelbaum EP, Bernard M, Bartelt VL, Zajac EJ, Stark D (2014) Ethnic diversity deflates price bubbles. Proc Natl Acad Sci 111(52):18524-18529

Liu B, Li Z (2018) Director-generals human and social capital, and management performance of farmers cooperatives: Evidence from China's Fujian. Int J Manag Econ 54(2):149-165

Madigan D, Raftery AE (1994) Model selection and accounting for model uncertainty in graphical models using Occam's window. J Am Stat Assoc 89(428):1535-1546

Mas-Collel W, Green DM (1995) Microeconomic theory. Oxford university Press, New York

MASSP (2018) Malawi strategy support program (ifpri). http://massp.ifpri.info/, accessed 16 Nov 2018

McKenzie D, Sakho YS (2010) Does it pay firms to register for taxes? the impact of formality on firm profitability. J Dev Econ 91(1):15-24

Messina JP, Peter BG, Snapp SS (2017) Re-evaluating the Malawian farm input subsidy programme. Nature Plants 3(4):17013

Miao C, Coombs JE, Qian S, Sirmon DG (2017) The mediating role of entrepreneurial orientation: a meta-analysis of resource orchestration and cultural contingencies. J Bus Res 77:68-80

Nowak MA (2006) Five rules for the evolution of cooperation. Science 314(5805):1560-1563

Okuguchi K (1993) Comparative statics for profit-maximizing and labor-managed Cournot oligopolies. Manag Decis Econ 14(5):433-444

Portes A (2014) Downsides of social capital. Proc Natl Acad Sci 111(52):18407-18408

Porto GG, Chauvin ND, Olarreaga M et al (2011) Supply chains in export agriculture, competition, and poverty in Sub-Saharan Africa. Centre for Economic Policy Research

Poulton C, Kydd J, Dorward A (2006) Overcoming market constraints on propoor agricultural growth in sub-Saharan Africa. Dev Policy Rev 24(3):243-277

Reny PJ, Perry M (2006) Toward a strategic foundation for rational expectations equilibrium. Econometrica 74(5):1231-1269

Sexton RJ, Xia T (2018) Increasing concentration in the agricultural supply chain: Implications for market power and sector performance. Ann Rev Resour Econ

Sitko NJ, Chisanga B, Tschirley D, Jayne TS (2018) An evolution in the middle: examining the rise of multinational investment in smallholder grain trading in zambia. Food Security 10(2):473-488

Smith JM (1988) Evolution and the theory of games. In: Did Darwin Get It Right? Springer, pp 202-215

Trivers RL (1971) The evolution of reciprocal altruism. Q Rev Biol 46(1):35-57

Van Rijn F, Bulte E, Adekunle A (2012) Social capital and agricultural innovation in sub-Saharan Africa. Agric Syst 108:112-122

Varian HR (2014) Intermediate microeconomics: a modern approach: Ninth International Student Edition. WW Norton \& Company

\section{Publisher's Note}

Springer Nature remains neutral with regard to jurisdictional claims in published maps and institutional affiliations. 